International Journal of Economics, Business and Accounting Research (IJEBAR)

Peer Reviewed - International Journal

Vol-5, Issue-1, 2021 (IJEBAR)

E-ISSN: 2614-1280 P-ISSN 2622-4771

http://jurnal.stie-aas.ac.id/index.php/IJEBAR

\title{
ADVERTISEMENT, LIFESTYLE AND PRODUCT QUALITY INFLUENCING PURCHASE DECISION OF XIAOMI SMARTPHONE IN SUKOHARJO
}

\author{
Bela Elmatiara, Bambang Mursito, Sudarwati \\ Universitas Islam Batik Surakarta \\ Jl. KH Agus Salim No. 10 Telp. (0271) 740160 Surakarta 57174 \\ E-mail: bellaelma123@gmail.com
}

\begin{abstract}
Changes occur in all fields including in the field of communication equipment, companies are always required to produce the latest products and the best innovations so that they are different from previous product and consumers want to buy them. The attractiveness of advertising that reminds and makes consumers interested in advertised products makes purchase demand increase, in addition to offering products through advertising the product must also meet the lifestyle of someone who wears it. In addition to the attractiveness of advertising and lifestyle, the quality of the product also greatly affects the product that will be launched to the public because the quality of the product will determine the price of the product. Researchers conducted this study to determine and explain the influence of advertising attractiveness, lifestyle and product quality in influencing purcha sing decisions for xiaomi smartphones in Sukoharjo. This recearch uses descriptive quantitative research with the independent variables of ad attractiveness, lifestyle and product quality. The sample population used is the entire Sukoharjo community, especially xiaomi smartphone users with a population of 3,780 people and a sample or 100 respondents, in taking the sample using purposive sapling technique and for data colletion using a questionnaire or questionnaire method. Based on the results of multiple linier regression tests, this study proves that the attractiveness of advertising, lifestyle and product quality have a significant effect on purchasing decisions together.
\end{abstract}

Keywords: Addractiveness of Ads, Lilestyle, Product Quality

\section{Introduction}

Changes occur in all fields including in the field of communication equipment, this is indicated by the many competition for the latest models, types and brands of mobile phones. Cellphones are a communication tool that has become a trend among people, from desawa, teenagers to children, from a form that is easy to carry anywhere. Cellphones also have sophisticated capabilities besides being used to send messages or make long distance calls. Cellphones are now not only used for making calls but can be used to make face-to-face video calls over long distances. The development of cellphones from the first time they came out until now has been very rapid in its development, making cellphone companies compete in releasing 
new products that can make consumers want to buy them. There are many cellphone brands on the market such as Samsung, Oppo, Realme, Apple, Nokia, Xiaomi and many more.

The attractiveness of advertisements or advertisements displayed in various media is the most important and important thing for close adaptation and communication with consumers, it can also attract consumers to always stay in the products offered and always remind consumers of the products offered because they always re-watch these advertisements. . This creates a relationship in advertising media with consumers to buy the products offered and creates communication between producers and consumers (Arpilia et al. 2018). The benefit of advertising in the products offered is to bring messages from producers to consumers. Advertising also has the benefit of retaining consumers with products that they always remember, advertising can be done in several ways, including: radio, ad impressions on television, magazines and other social for example: Instagram, Facebook, etc.

Lifestyle describes a person as a whole who interacts with their environment (Kotler and Keller, 2009,175). In the current era of technology, Xiaomi is a smartphone that is well known among the public, especially in Indonesia, with affordable prices and product innovations that are increasingly making consumers want to buy it. What makes xiaomi attractive to consumers is the MIUI firmware which almost resembles Samsung Touchwis and iOS from Apple, and has advantages in its camera. Lifestyles have changed over time, for example in the field of technology, people who used to have enough cellphones for phones and sending short messages, but now people choose to buy smartphones that can be used for internet, video calls, etc.

The company must be able to improve the quality of the products produced, it will be very helpful to always prioritize and maintain the position of the product in its target market (Amalia 2017). Not only offering products that have good quality and affordable prices, the company also has the ability to deliver products to consumers through promotional media intermediaries, namely advertisements which are important in doing business. This advertising promotion aims to emphasize the advantages of the product owned and to encourage consumers to buy, with interactions with buyers and other people, it will ultimately influence purchasing decisions (Daniel et al. 2016).

\section{UNDERLYING THEORY}

\section{Purchasing decisions}

Purchasing decisions, namely where the process occurs before consumers purchase a product by going through several processes in decision making, namely where it can influence purchase intention until consumers make a purchase decision or decision to use is the attraction of product advertisements and product image itself (Aprilia et al. 2018) Purchasing decisions are one of the main components of consumer behavior decisions. Consumer purchases are the step by step consumers use when buying goods and services (Lamb, 2008, 23). 


\section{Advertising Appeal}

Daya. Interested in advertising. Is where the message is different from the others, namely by showing a short story in real life, whether a group or individual with a fantasy lifestyle according to the product offered, with a delivery that fits the heart of the product image and is equipped with musical innovations for animate the ad. In this way, advertisements appear that will have their own appeal and grow the product image (Aprilia et al. 2018). Advertising has an important communication function for a company or organization's products (Shimp, 2003, 357).

\section{Lifestyle}

Lifestyle is the main factor that influences purchasing decisions. Lifestyle has the potential to increase a person's degree, therefore where people use their money and time (Ivan 2019) . and. take advantage of the time.

\section{Product quality}

Product quality is the main tool for entrepreneurs to determine the position of their products in the market. Each company is obliged to choose the quality of the products it will produce to support and enhance and maintain the company's position in the highest position. (Amalia et al. 2017). Kotler and Armstrong (2010, 273) define product quality as the totality of features and characteristics of a product or service that depend on its ability to satisfy stated or implied needs. Product quality is the overall combination of product characteristics resulting from marketing, engineering, production and maintenance that makes these products usable to meet customer or consumer expectations (Wijaya, 2011, 11) Product quality is a product or service characteristic that depends on its ability to satisfy customer needs. which is stated or implied.

\section{Thingking Framework}

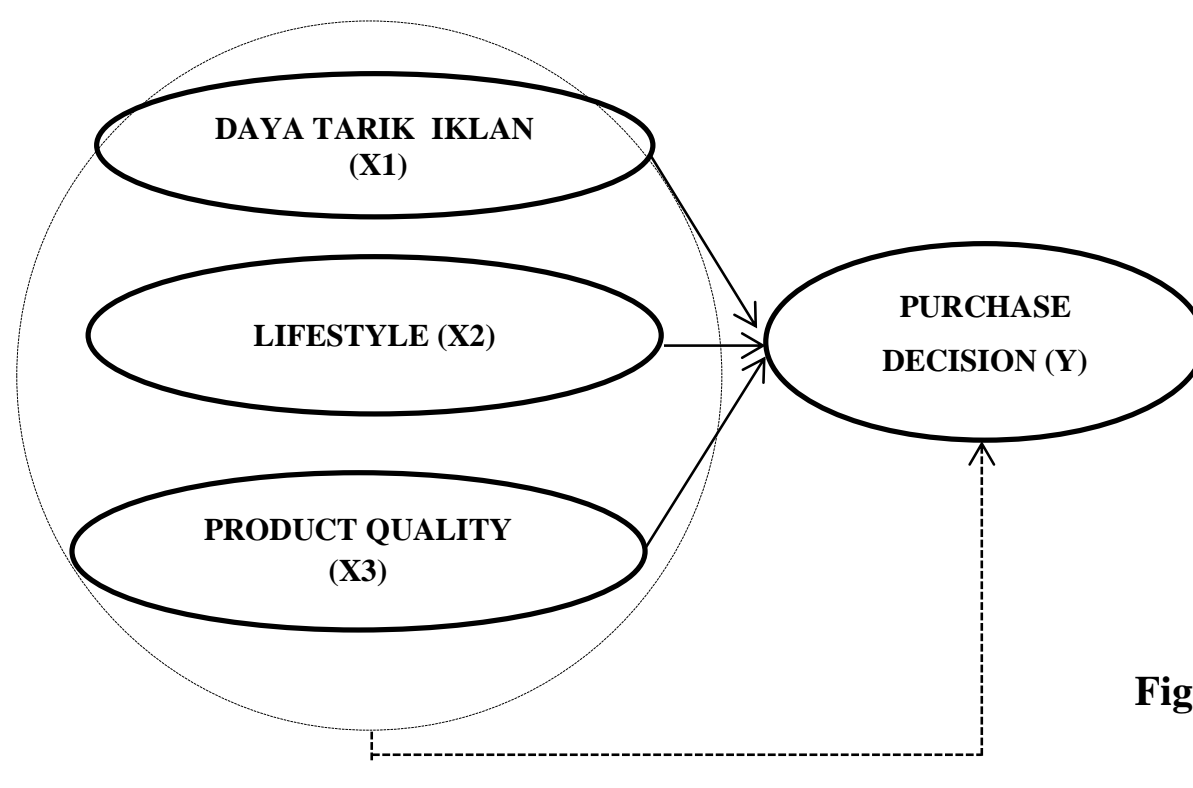

Figure 1. Thinking Framework 
Keterangan :

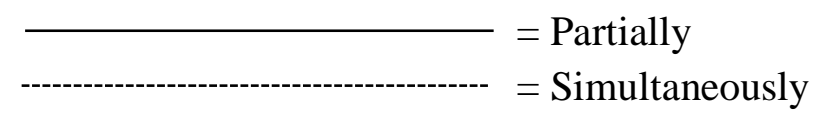

\section{Hypothesis}

$\mathrm{H}_{1}$ : The attractiveness of advertising has a significant effect on purchase decisions

$\mathrm{H}_{2}$ : Lifestyle has a significant effect on purchasing decisions

$\mathrm{H}_{3}$ : Product quality has a significant effect on purchasing decisions

$\mathrm{H}_{4}$ : The attractiveness of Lifestyle Ads and Product Quality have a simultaneous and significant effect on purchasing decisions

\section{Research Method}

This research uses survey or field research and quantitative research methods. Sampling using purposive sampling technique with a sample size of 100 respondents whose population is 3,780 people, namely the people of Sukoharjo, to be precise, the xiaomi smartphone users, the method used in this study used the data analysis method with multiple linear regression namely $\mathrm{t}$ test, $\mathrm{f}$ test and test of determination. This research was conducted for 6 months from September 2020-February 2021. With data collection techniques using a questionnaire or questionnaire.

\section{Result And Discussion}

\section{Result}

The results of research conducted through a questionnaire or questionnaire are distributed with 20 questions, each of which is 5 questions. In this study, the criteria determined were males and females with adolescence, adults, children and the elderly who live in Sukoharjo. Xiaomi smartphone users are prioritized. The description of this study begins with knowing the character of the respondent with demographic factors, including age, latest education, occupation and monthly income. Then determine the effect of advertising attractiveness, lifestyle and product quality on purchasing decisions for xiaomi smartphones in Sukoharjo. After the primary data that has been collected through a questionnaire, the validity test, reliability test, classical assumptions are then carried out by analyzing the data using multiple linear regression analysis and using $\mathrm{t}$ test and $\mathrm{f}$ test. Using the help of the computer program SPSS 16.0 (Statistic Program for Social Science) for Windows.

Table 1

Characteristics of Respondents Based on Demographics

\begin{tabular}{|c|c|c|c|}
\hline \multicolumn{2}{|c|}{ Respondent characteristics } & Amount & Percentage (\%) \\
\hline \multirow{2}{*}{ Gender } & Man & 30 & 30 \\
\cline { 2 - 4 } & Woman & 70 & 70 \\
\hline \multirow{2}{*}{ Age } & Total & $\mathbf{1 0 0}$ & $\mathbf{1 0 0}$ \\
\hline \multirow{2}{|c|}{$<15$ tahun } & 2 & 2 \\
\hline
\end{tabular}


International Journal of Economics, Business and Accounting Research (IJEBAR)

Peer Reviewed - International Journal

Vol-5, Issue-1, 2021 (IJEBAR)

E-ISSN: 2614-1280 P-ISSN 2622-4771

http://jurnal.stie-aas.ac.id/index.php/IJEBAR

\begin{tabular}{|c|c|c|c|}
\hline & 16-20 tahun & 29 & 29 \\
\hline & 21-26 tahun & 44 & 44 \\
\hline & 27-30 tahun & 16 & 16 \\
\hline & $>30$ tahun & 9 & 9 \\
\hline \multicolumn{2}{|r|}{ Total } & 100 & 100 \\
\hline \multirow{5}{*}{ Last education } & Junior High School & 6 & 6 \\
\hline & Senior High Shool & 48 & 48 \\
\hline & Diploma & 7 & 7 \\
\hline & S1 & 33 & 33 \\
\hline & Others & 6 & 6 \\
\hline \multicolumn{2}{|r|}{ Total } & 100 & 100 \\
\hline \multirow{4}{*}{ Occupation } & College student & 47 & 47 \\
\hline & Civil Servant & 12 & 12 \\
\hline & General employees & 27 & 27 \\
\hline & Others & 14 & 14 \\
\hline \multicolumn{2}{|r|}{ Total } & 100 & 100 \\
\hline \multirow{4}{*}{ Income/month } & < Rp. 1.000 .000 & 24 & 24 \\
\hline & Rp.1.000.000 - Rp. 2.000 .000 & 26 & 26 \\
\hline & Rp.2.000.000 - Rp. 3.000.000 & 28 & 28 \\
\hline & $>$ Rp. 3.000 .000 & 22 & 22 \\
\hline \multicolumn{2}{|r|}{ Total } & 100 & 100 \\
\hline
\end{tabular}

Source: Primary data processed, 2020

Based on the table above, it can be seen the number of respondents according to the criteria that have been determined in this study. Judging from the criteria for gender, it shows that the most dominant is male with a $70 \%$ pretense because the xiaomi smartphone has high specifications. When viewed from the age criteria, the most dominant age is 22-26 years which has a percentage of $44 \%$ because at that age the majority of adolescents like smartphones with the best camera quality and specifications.

Judging from the latest education criteria, the most dominant is SMA / SMK which has a percentage of $48 \%$ because at this age most of them are already working and are still young with high tastes and lifestyles. While the job criteria that we can see the most dominant are students with a percentage of $47 \%$ because teenagers have a high interest in having a smartphone with a good camera quality and the best specifications. The latter can be seen in the job criteria with a monthly income of Rp. 2,000,000-Rp. 3,000,000 percentage $28 \%$ because the majority of respondents who are already working and have a side job besides being a student or college student, this income will be fulfilled to buy the smartphone they want. 
Table 2

Multiple Linear Regression Coefficient Results

\begin{tabular}{lcccc}
\hline \multicolumn{1}{c}{ Variable } & B & T count & Sig. & Description \\
& 2,826 & & & \\
\hline Advertising Appeal (X1) & 0,219 & 2,615 & 0,010 & Signifikan \\
Lifestyle (X2) & 0,209 & 2,924 & 0,004 & Signifikan \\
Product Quality (X3) & 0,463 & 5,723 & 0,000 & Signifikan \\
Coefficient & & Hasil & Uji F & Hasil \\
R & & 0,876 & F hitung & 105,195 \\
R Square (R $\left.{ }^{2}\right)$ & & 0,767 & & \\
Adj R Square (Adj R $\left.{ }^{2}\right)$ & & & & \\
Y $=$ a+b1X1+b2X2+b3X3+e & & & & 0,000 \\
Y $=2,826+0,219 \mathrm{X}_{1}+0,209 \mathrm{X}_{2}+0,463 \mathrm{X}_{3}+\mathrm{e}$ & & & & \\
\hline
\end{tabular}

Source: Primary Data, 2020

From table 2 above, it can be obtained a multiple linear regression marketing model as follows:

$\mathrm{Y}=2,826+0,219 \mathrm{X}_{1}+0,209 \mathrm{X}_{2}+0,463 \mathrm{X}_{3}+\mathrm{e}$

Y: Purchase Decision

$\mathrm{X} 1$ : Advertising appeal

X2: Lifestyle

X3: Product Quality

In the multiple linear regression analysis model above explains that:

a. The constant value of 2.826 means that the dependence value of purchasing decisions on the variables of advertising attractiveness, lifestyle and product quality is quite high.

b. The advertising attractiveness variable has a positive effect on purchasing decisions with a coefficient value of 0.219 which indicates that if there is an increase of $1 \%$ in the advertising attractiveness variable while the lifestyle and product quality variables are constant, the xiaomi smartphone purchase decision will increase by 0.219 .

c. Lifestyle variables have a positive effect on purchasing decisions with a coefficient value of 0.209 which indicates that if there is an increase of $1 \%$ in the lifestyle variable while the variables of advertising attractiveness and product quality are constant, the xiaomi smartphone purchase decision will increase by 0.209 .

d. The variable (Product Quality has a positive effect on purchasing decisions with a coefficient value of 0.463 which indicates that if there is an increase of $1 \%$ in the product quality variable, while the lifestyle variables and advertising attractiveness are constant, the xiaomi smartphone purchase decision will increase by 0.463 .

\section{Coefficient of Determination}

The results of calculations using the SPSS 16.00 program prove that the value of R2 is 0.759 , meaning that $75.9 \%$ of the independent variables can affect the dependent variable, while 
the remaining $24.1 \%$ is influenced by variables that researchers have not done, for example consumer motivation, celebrity endorser, and excellence. product.

\section{Simultaneous Hypothesis Test (Test F)}

The attractiveness of advertising, lifestyle and product quality have a simultaneous influence on purchasing decisions for Xiaomi smartphones in Sukoharjo.

\section{Partial Hypothesis Testing ( $t$ test)}

1) The advertisement attractiveness variable, the value of $t$ count 2.615 is greater than the ttable value of 1.98498 with a significant level of $0.010<0.05$ means that Ho is rejected, so it shows that advertising attractiveness has a significant effect on purchasing decisions for xioami smartphones.

2) Lifestyle variable, the value of tcount 2.924 is greater than the t-table value of 1.98498 with a significant value of $0.004<0.05$, which means that Ho is rejected, so this shows that lifestyle has a significant effect on purchasing decisions for xioami smartphones.

3) The variable of product quality, the value of t count 5.723 is greater than the value of t table 1.98498 with a significant value of $0.000<0.05$, which means that Ho is rejected, so it shows that product quality has a significant effect on purchasing decisions Xioami smartphone.

\section{Discussion}

\section{Effect of Attractiveness of Ads in Influencing Purchasing Decisions}

The results showed that the advertising attractiveness variable had a significant effect on purchasing decisions for xiaomi smartphones in Sukoharjo because the regression coefficient value indicated that the attractiveness of advertising in Xiaomi smartphones had a high value. According to (Nurmayanti and Pristiyono 2016). The attractiveness of advertising has a positive and significant effect on purchasing decisions. Mitsubishi Pajero Sport at PT. Sumatera Berlian Motor, the first hypothesis concluded that the higher the value of the attractiveness of the advertisement, the higher the consumer's buying interest.

From this study that the advertising attractiveness variable has a positive effect on purchasing decisions, the better the attractiveness of the ad, the better the decision to buy a Xiaomi smartphone in Sukoharjo. The attractiveness of xiaomi smartphone advertising is able to influence xiaomi smartphone purchasing decisions due to the ad "HAPE KECE BATER GEDE". It is a characteristic of xiaomi advertisements that consumers can trust so that xiaomi is more widely known by the public.

\section{The Effect of Lifestyle in Influencing Purchasing Decisions}

The results of the study prove that lifestyle variables have a significant effect on purchasing decisions for xiaomi smartphones in Sukoharjo because the regression coefficient values show 
that the current lifestyle is very influential in purchasing high-quality smartphones. According to (Nata et al. 2018) The results of the path analysis show that lifestyle variables have a direct influence and show that there is a lifestyle influence on purchasing decisions that occur if the percentage is $50.9 \%$.

In this study, lifestyle variables have a positive effect on purchasing decisions, the higher the lifestyle, the higher the purchasing decision in choosing a Xiaomi smartphone because in this modern era, smartphones are a primary need for society, especially teenagers and children who always pay attention to the type of model. latest product and want to have it with the taste meets his lifestyle.

\section{The Effect of Product Quality in Influencing Purchasing Decisions}

The results showed that the variable product quality had a significant effect on purchasing decisions Xiaomi smartphones in Sukoharjo because the regression coefficient value showed that consumers really determine the quality of the product in deciding the purchase of a product according to (Doni et al. 2016). Based on the results of the partial test, it can be concluded that the variable product quality has a significant effect on purchasing decisions because product quality has a high enough role in determining purchasing decisions.

In this study, the variable product quality has a significant effect on purchasing decisions, the more quality the xiaomi product, the higher the purchasing decision for the xiaomi smartphone. The world of electronics is now very tight competition, especially smartphones which are always competing to launch new products that have the best quality to attract consumers to buy them.

\section{Conclusion}

The conclusions in this study are:

1) The results show that the attractiveness of advertising, lifestyle and product quality together have a significant effect on purchasing decisions for Xiaomi smartphones in Sukoharjo.

2) The attractiveness of advertising has a significant effect on purchasing decisions for Xiaomi smartphones in Sukoharjo.

3) Lifestyle has a significant effect on purchasing decisions for xiaomi smartphones in Sukoharjo.

4) Product quality has a significant effect on purchasing decisions for xiaomi smartphones in Sukoharjo.

The limitation in this study is that $75.9 \%$ of the independent variables can affect the dependent variable, while the remaining $24.1 \%$ is explained by other variables not observed in this study, for further research it can further explain consumer motivation, celebrity endorsers, and product advantages. 


\section{REFERENCES}

Amalia, S. (2017). Pengaruh Citra Merek, Harga, Dan Kualitas Produk Terhadap Keputusan Pembelian Handphone Merek Xiaomi Di Kota Langsa. Jurnal Manajemen Dan Keuangan, 660-669.

Aprilia , A., A.L.H.V Jovee, L., \& Yunita, M. (2018). The Influence Ad Attaction And Product Image To The Purchasing Decision Of Chitato Product In The Student Feb Unsrat. Pengaruh Daya Tarik dan Citra Produk Terhadap Keputusan Pembelian Produk chitato Chips Pada Mahasiswa FEB Unsrat, Vol.6, No. 2 (Issn 2303-1174), 988-997.

Bulan , Lindung, P., Muhammad, R., \& Wahyu , A. (2019). Pengaruh Bauran Pemasaran, Celebrity Endorser Dan Gaya Hidup Terhadap Keputusan Pembelian Sepeda Motor Merek Honda Beat. Jurnal Manajemen Inovasi, 88-97.

D. Tampi., A. S. (2016). Pengaruh Kualitas Produk, Harga, Dan Daya Tarik Iklan Terhadap Keputusan Pembelian Sepeda Motor Honda Scoopy Pada Pt. Daya Adicipta Wisesa. Jurnal Emba, Vol 4, No. 1, 990-999.

Ivan. (2019). Pengaruh Gaya Hidup Dan Persepsi Konsumen Terhadap Keputusan Pembelian Produk Tan Authentic

Kotler, Philip and Gary Armstrong, 2010. Priciples of Marketing. Edisi 9 Prentive Hall Inc. New Jersey

Mughnifar, I. (2020, April 5). Materibelajar.Co.Id. Dipetik April 5, 2020, Dari Https://Www.Materi.Carageo.Com/Pengertian-Sampel-Menurut-Para-Ahli/

Pengajarku. (2020, Agustus 6). Pengajar Co.Id . Dipetik Agustus 6, 2020, Dari Https://Pengajar.Co.Id/Gaya-Hidup-Adalah/

Rina, H. (2019, September 1). Penelitian Ilmiah.Com. Dipetik Juni 16, 2019, Dari Https://Penelitianilmiah.Com/Teknik-Sampling/

Shimp, Terence A. 2014 "Komunikasi Pemasaran Terpadu dalam Periklanan dan Promosi”.

Jakarta: Salemba Empat

Sumarwan, Ujang. 2011. Perilaku Konsumen. Bogor: Ghalia Indonesia.

Wijaya, T. 2011. Manajemen Kualitas Jasa. Edisi1. Indeks. Jakarta.

Zufaldi, M., Susi , E., \& Whyosi , S. (2019). Pengaruh Daya Tarik Iklan, Harga Dan Electronic Word Of Mouth (Ewom) Terhadap Minat Pengguna Jasa Transportasi Online Grab Di Kota Padang. Jurnal Kajian Manajemen Dan Wirausaha, Vol.1, No.1, 380-387. 